Making Health Work 
Studies in Demography

General Editors

Eugene A. Hammel

Ronald D. Lee

Kenneth W. Wachter

I. Douglas S. Massey, Rafael Alarcón, Jorge Durand, and Humberto González, Return to Aztlan: The Social Process of International Migration from Western Mexico

2. Ronald R. Rindfuss, S. Philip Morgan, and Gray Swicegood, First Births in America: Changes in the Timing of Parenthood

3. Judith Blake, Family Size and Achievement

4. Ron J. Lesthaeghe, ed., Reproduction and Social Organization in Sub-Saharan Africa

5. Lee L. Bean, Geraldine P. Mineau, and Douglas L. Anderton, Fertility Change on the American Frontier: Adaptation and Innovation

6. Frances K. Goldscheider and Linda J. Waite, New Families, No Families? The Transformation of the American Home

7. David I. Kertzer and Peter Laslett, eds., Aging in the Past: Demography, Society, and Old Age

8. Carl Mosk, Making Health Work: Human Growth in Modern Japan 


\section{Making Health Work}

Human Growth in Modern Japan

\section{Carl Mosk}

UNIVERSITY OF CALIFORNIA PRESS

Berkeley · Los Angeles · London 
University of California Press

Berkeley and Los Angeles, California

University of California Press

London, England

Copyright $(1996$ by The Regents of the University of California

Library of Congress Cataloging-in-Publication Data

Mosk, Carl.

Making health work : human growth in modern Japan / Carl Mosk.

p. $\mathrm{cm}$.- (Studies in demography : 8)

Includes bibliographical references and index.

ISBN 0-520-083 I 5-6 (alk. paper)

r. Quality of life-Japan. 2. Human growth-Japan.

3. Anthropometry-Japan. 4. Japan-Population. I. Title.

II. Series: Studies in demography (Berkeley, Calif.) : 8.

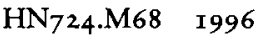

$573^{\prime} .6^{\prime} 0952-\mathrm{dc} 20$

96-26629

CIP

Printed in the United States of America

$\begin{array}{lllllllll}1 & 2 & 3 & 4 & 5 & 6 & 7 & 8 & 9\end{array}$

The paper used in this publication meets the minimum requirements of American

National Standard for Information Sciences-

Permanence of Paper for Printed Library Materials,

ANSI Z39.48-I 984 
to my mother, Mary B. Hanley and to the memory of my father, Sanford A. Mosk 
